\title{
Land use and biotic integrity in shallow streams of the Hondo River basin, Yucatán Peninsula, Mexico
}

\author{
Rodrigo I. Pacheco-Díaz, Juan J. Schmitter-Soto*, Birgit Schmook, Gerald A. Islebe \\ \& Holger Weissenberger \\ El Colegio de la Frontera Sur, Apdo. Postal 424, MX-77000 Chetumal, Mexico; rpacheco@live.com.mx, \\ jschmitt@ecosur.mx, bschmook@ecosur.mx, gislebe@ecosur.mx, holgerweissen@ecosur.mx \\ * Correspondence
}

Received 21-III-2017. Corrected 18-VII-2017. Accepted 16-VIII-2017.

\begin{abstract}
Aquatic environments face a variety of threats in the Hondo River basin, Southeastern Yucatán Peninsula. Some of these impacts, like pollution by pesticides, may depend on land use and cover. Our objective was to assess the effect of land use/cover using a previously published index of biotic integrity (IBI), based on fishes and designed for shallow streams in the Hondo River basin. Our hypothesis was that land uses that cause deforestation and pollution, such as urbanization, cattle breeding, or sugar cane fields, would be reflected in low IBI values, at least at some spatial scales. The 23 sites originally used in 2008-2009 to estimate by electrofishing the relative abundance and other characteristics of selected fish species and guilds to construct the IBI, were revisited in February 2010, to validate by direct inspection the type of land use/cover suggested by landscape information in digital databases. We analyzed the effect of seven types of land use/cover (agriculture, pasture, human settlements, water bodies, wetlands, forest, and secondary vegetation) on the IBI values, at four spatial scales, i.e., the percent of every land use/cover at progressively larger circles $(125,250,500$, and $1000 \mathrm{~m}$ diameter) centered on the water body where the IBI value was measured. Correlations were established among the percent land/use cover by scale around 23 sites, and with their corresponding IBI values. Then, Student's $t$ tests were calculated to examine significant differences in land use/cover between groups of localities above and below the median IBI value, and Mann-Whitney's $U$ tests were applied to compare IBI values between localities with and without a given landscape cover. Agriculture, human settlements, and secondary vegetation correlated negatively with the IBI; forests positively. Differences were significant $(\mathrm{p}<0.05)$ for forest (higher in sites with higher IBI values) and human settlements (lower in sites with higher IBI). Of all the landscape categories located in the Hondo River basin, with the exception of pasture, those of anthropogenic origin tended to be detrimental to aquatic biotic integrity. Rev. Biol. Trop. 65 (4): 1448-1458. Epub 2017 December 01.
\end{abstract}

Key words: human impact, fishes, environmental risk, landscape dynamics, index of biotic integrity, aquatic diversity.

Along the Mexican-Belizean Hondo River basin, most human settlements used to subsist on forestry, agriculture, livestock, and tourism (although since the early 2000s most of them rely on government subsidies and remittances from the United States or from Cancún and Playa del Carmen: Castellanos, 2010). Some of these activities threaten freshwater systems due to creation of waste, such as organic matter and pesticides, among others. Agriculture, transport, and urban residual water are the main sources of pollution (Buenfil-Rojas, Álvarez-Legorreta, \& Cedeño-Vázquez, 2014; Sánchez, Álvarez-Legorreta, Pacheco, Carrillo, \& González, 2016). Additionally, the presence of invasive species in the region, like tilapia Oreochromis mossambicus (Peters, 1852) and its hybrids, as well as armored catfish Pterygoplichthys pardalis (Castelnau, 1855) and the partial or total physical modification of the landscape at different scales threaten freshwater bodies and their biota (Schmitter-Soto 
\& Caro, 1997; Esselman, Schmitter-Soto, \& Allan, 2013; Schmitter-Soto, Quintana, ValdézMoreno, Herrera-Pavón, \& Esselman, 2015).

The most important land use changes in the Hondo River basin are the conversion of natural vegetation to sugar cane plantations, pasture for cattle, physical changes of the water channel to create touristic facilities, and local tilapia production. This affects riparian systems, which possess high biodiversity and provide environmental services, food and recreational resources for the local population. Riparian ecosystems are also highly vulnerable to natural disturbances, such as floods or fires (Naiman et al., 2005).

Indices of biotic integrity (IBI) are useful tools for the estimation of current ecosystem condition, as they integrate information at multiple levels of biological organization and at different spatial scales (Karr, 1981). Therefore, IBI are complementary indicators to physical and chemical methods to estimate ecosystem health, although a serious drawback is the fact that they need to be tailored specifically almost for every basin, due to natural differences in biogeography and ecology. These indices, originally developed for streams, have also been applied to other aquatic environments, e.g. estuaries (Fisch, Branco, \& Menezes, 2016). Besides fish, other organisms have been used as indicators, for example plants and invertebrates (Wilcox et al., 2002), diatoms (Fore, 2002), and even birds (Córdova-Ávalos, Alcántara-Carbajal, Guzmán-Plazola, Mendoza-Martínez, \& González-Romero, 2009).

In Mexico, IBI have been developed mostly for rivers and lakes (Schmitter-Soto, 2014). Schmitter-Soto, Ruiz-Cauich, Herrera-Pavón, and González-Solís (2011) developed a fishbased IBI for shallow streams in the Hondo River basin, based mainly on the relative abundance of selected opportunistic species and sensitive ecological guilds.

Some studies have incorporated landscape components to analyze their influence on IBI values, in North (e.g. Richards \& Host, 1994; Snyder, Young, Villella, \& Lemarié, 2003), South (Pinto, Araújo, \& Hughes, 2006) and
Central America (van Oosterhout \& van der Velde, 2014), but no such analysis is yet available for Mexico. Thus, the aim of this study was to assess the effect of the land use/cover mosaic on the IBI based on fishes, as developed by Schmitter-Soto et al. (2011) for the Hondo River basin, Mexico. Our hypothesis was that land uses involving deforestation and pollution, such as urbanization, cattle breeding, or sugar cane fields, would correlate with low IBI values, at least at some spatial scales.

\section{MATERIAL AND METHODS}

The study area is located in the Southeastern Yucatán Peninsula, in the Mexican part of the Hondo River basin (Fig. 1). The limits of the Hondo River basin are not well defined, but we estimated an extension of $8174 \mathrm{~km}^{2}$ in the Mexican side. The highest tributaries flow from a plateau at ca. $250 \mathrm{~m}$ above sea level, with no clear watershed to divide them from adjacent basins. The river's main course follows a geological fault and, as its tributaries, flows slowly, with a slope always less than $5^{\circ}$. Typical soils are regosols, vertisols, and rendzines (Arriaga Cabrera et al., 2000). The climate is warm and sub-humid, with an average annual rainfall from 1200 to $1400 \mathrm{~mm}$, and a mean temperature of $24-28{ }^{\circ} \mathrm{C}$ (INEGI, 2009), although in recent years precipitation has fluctuated greatly (IPCC, 2013). The natural vegetation is mostly medium subdeciduous forest, dominated by Manilkara zapota (L., 1759), Bucida buceras L., 1759, or Cryosophila stauracantha (Heynh., 1846), as well as mangrove and other aquatic vegetation (Miranda, 1958).

In this study, an IBI created for shallow streams in the Hondo basin (Schmitter-Soto et al., 2011), was analyzed as a function of landscape-level data. The IBI was developed from 23 sampling sites distributed on the Mexican side of the Hondo River basin (Fig. 1A). This index used twelve metrics based on fishes, with a maximum score of 60 and a minimum of zero; details are given by Schmitter-Soto et al. (2011), who also provided environmental data for every sampled locality used to design 

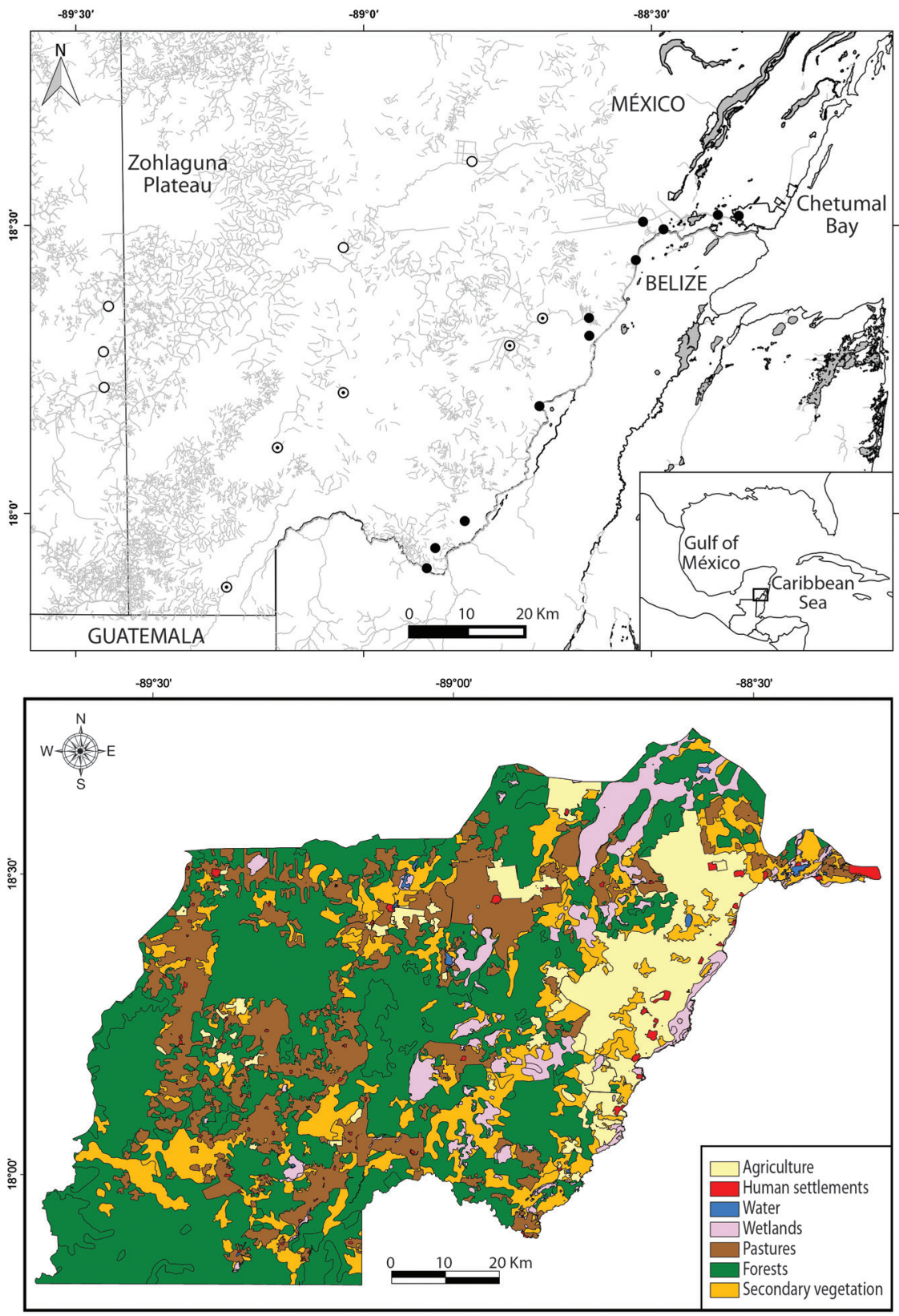

Fig. 1. Study area in the Hondo River basin, with (A) sampled localities in the context of permanent and intermittent surface water flows, and (B) identified land-uses (modified from Pacheco Díaz, 2011, and Schmitter-Soto et al., 2011). Locality symbols: upper basin, open circles; middle basin, circles with a centered dot; lower basin, solid circles.

or test the index. No new components were added to the IBI.

To collect field data for landscape variables, all locations used to construct the IBI
(Schmitter-Soto et al., 2011) were visited in February 2010. At each site, a visual survey of the natural vegetation and land use (agriculture, pasture for cattle, secondary vegetation, 
among others) was conducted. A Garmin global positioning system device was used to georreference the sites. Subsequently, the type of vegetation at each site was determined, using the vegetation classification for the Yucatán Peninsula by Miranda (1958). This field information was used to corroborate available digital databases and maps (García \& Secaira, 2006; INEGI, 2009). The data were processed with the geographic information system ArcView 3.2 (ESRI, 1999). Coverage and extension of agricultural and livestock activities, delimitation of the basin, and land use were recorded, and a land use and land cover map was produced (Fig. 1B).

On the land use and land cover map, progressively larger circular buffers $(125,250$, 500 , and $1000 \mathrm{~m}$ ) were defined around each of the sampling sites in order to measure the coverage (in $\mathrm{m}^{2}$ ) at different scales for each land use/cover class at each site. A multiple Pearson correlation analysis was performed among the percentage covers for each landscape (land use/land cover) class and the local IBI values. In addition, Student's $t$ tests were calculated to look for significant differences in cover between high- and low-IBI groups of localities (above and below the median IBI value), and Mann-Whitney's $U$ tests were applied to compare IBI values between localities with vs. without a given landscape cover. Significance in all cases was set at $\mathrm{p}<0.05$; we used the program Infostat, vers. 2008 (di Rienzo et al., 2008), and the website Vassarstats (Lowry, 2016).

\section{RESULTS}

For February 2010, we identified 17 land use and land cover types, which were grouped into seven categories or classes for analysis: agriculture, pasture, human settlements, water bodies, wetlands, forest, and secondary vegetation (Table 1; Fig. 1B).

Considering altitudinal stratification, we found that the upper and middle basin was dominated by forest, followed by pasture; the other classes did not exceed $20 \%$ of the remaining coverage. In the lower basin two classes dominated, namely forest and agriculture, followed by secondary vegetation (Figs. $1 \mathrm{~B}, 2)$. In the lower basin we found a larger area occupied by wetlands, water bodies, and human settlements. Pasture in the lower basin represented a smaller percentage than in the other two altitudinal sections (Fig. 2). Using any of the four different scales of analysis, pasture had the highest percentage of land cover, ranging from 31 to $37 \%$; agricultural use had a range of 24 to $26 \%$; wetlands from 7 to $14 \%$, secondary vegetation from 8 to $12 \%$; forests from 6 to $10 \%$; human settlements from 6 to $9 \%$, and water bodies from 2 to $9 \%$.

The correlation between the IBI for the Hondo River basin and the different land use/ cover classes was similar at all scales, always either negative or positive. Correlation was inverse between the index and agriculture $(\mathrm{r}=-0.17$ to -0.32$)$. Human settlements also presented an inverse correlation to the IBI ( $\mathrm{r}$ $=-0.15$ to -0.46 ), as did secondary vegetation

TABLE 1

Land use/cover classes in the Hondo River basin

\begin{tabular}{llc}
\multicolumn{1}{c}{ Classes } & \multicolumn{1}{c}{ Land use and land cover } & Cover (\%) \\
Forest & High and medium subdeciduous forest & 45 \\
Pasture & Pasture for cattle raising & 17 \\
Secondary vegetation & Secondary vegetation & 16 \\
Agriculture & Irrigation and temporal agriculture & 12 \\
Wetlands & Mangrove, riparian vegetation and other hydrophytes & 8 \\
Human settlements & Human settlements & 1 \\
Water bodies & Lakes, cenotes, rivers, and streams & 1 \\
\hline
\end{tabular}




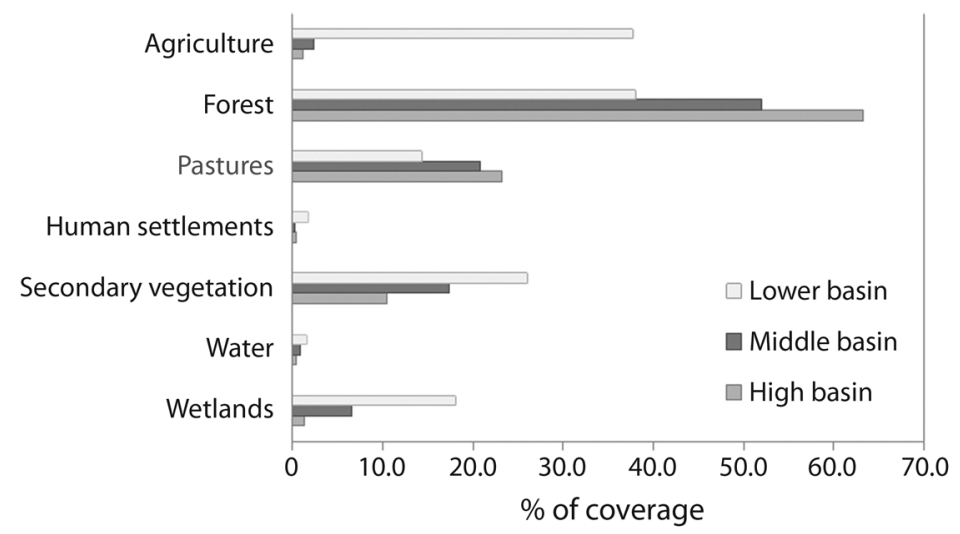

Fig. 2. Distribution of land use/cover in the different altitude layers in the Hondo River basin.

TABLE 2

Correlation between land use/cover types and IBI values (only Scale 4, $1000 \mathrm{~m}$, shown)

\begin{tabular}{lcccccccc} 
& agric & forst & past & settl & secve & water & wetln \\
IBI & -0.18 & 0.26 & 0.16 & -0.45 & -0.18 & -0.27 & 0.40 \\
agric & 1 & -0.34 & -0.74 & 0.08 & -0.22 & -0.18 & -0.08 \\
forst & & 1 & 0.05 & -0.39 & -0.21 & -0.12 & -0.12 \\
past & & & 1 & -0.33 & -0.27 & -0.24 & -0.23 \\
settl & & & & 1 & 0.37 & 0.55 & -0.05 \\
secve & & & & & & 0.44 & 0.20 \\
water & & & & & 1 & 0.29 \\
\hline
\end{tabular}

Abbreviations: agric, agriculture; forst, forest; past, pasture; settl, human settlements; secve, secondary vegetation; wetln, wetlands.

$(\mathrm{r}=-0.19$ to -0.28$)$. Positive correlations existed for pasture ( $\mathrm{r}=0.15$ to 0.23$)$, wetlands $(\mathrm{r}=0.32$ to 0.40$)$, and forests ( $r=0.20$ to 0.23 ). Several land use/cover types were correlated among themselves, e.g. water bodies, secondary vegetation, and human settlements; agriculture and pasture were strongly inversely correlated, almost mutually exclusive (Table 2).

However, only two differences between groups of localities were found to be statistically significant: Localities with a high IBI (>50) had a mean forest cover of $62.5 \%$ vs. only $10.0 \%$ for sites with lower IBI $(\mathrm{t}=5.4)$. Localities with any human settlement cover had lower IBI values (mean 42.3) than those without human settlements (IBI mean 46.5; $\mathrm{U}=29.5$ ).

\section{DISCUSSION}

In general, studies of land use on stream condition have found that, where forests dominate (at least in temperate regions), IBI values tend to be higher (i.e., biotic integrity is better). In contrast, in localities with a high proportion of agriculture $(>40 \%)$ and human settlements, the IBI tends to be lower (Roth, Allan, \& Erickson, 1996; Allan, Erickson, \& Fay, 1997; Allan, 2004).

In our study, agriculture had an inverse (although not significant) correlation to biotic integrity. In streams of Wisconsin (Richards \& Host, 1994) and Michigan (Roth et al., 1996) the inverse correlation was significant 
and strong, up to $r=-0.70$. Similarly, Wichert and Rapport (1998) found that fish communities significantly declined in streams in Southern Ontario as agriculture intensified. For streams in Illinois, Fitzpatrick, Scudder, Lenz, and Sullivan (2001) reported that IBI values tend to be low when agriculture cover is $>10 \%$ in the stream buffer zone $(r=-0.76)$. In our study area, the main agricultural activity (close to $100 \%$ of the agriculture cover in the lower basin) was sugar cane production, which causes a large deposition of sediment, fertilizers and herbicides in surrounding water bodies (Yu, DeLaune, Tao, \& Beine, 2008). Carpenter et al. (1998) analyzed nutrient enrichment from crop fields and observed an increase in trophic levels, increasing production and biomass of many organisms, resulting in changes in species composition, usually with lower diversity (evenness).

Riparian vegetation is usually sparse in agricultural areas, and streams are modified given the spatial distribution and irrigation of fields, thus affecting fish communities, since the structure of riparian zones in turn affect the structure of aquatic habitats (Roth et al., 1996), especially because of a lack of vegetation in the stream banks, where many fish species find shelter as young. Nevertheless, Wang, Lyons, Kanehi, Bannerman, and Emmons (2000) commented that urban uses are more harmful to environmental health than agriculture (because of the increased runoff, which alters the stream physically and chemically), and Snyder et al. (2003) even reported a positive relationship between the spread of agriculture and a fishbased IBI (although their finding might be due to including pasture and row-crops in the same land-use category).

Biotic integrity was significantly lower where urban areas increased; this expected result is consistent with most findings elsewhere (e.g. Pinto et al., 2006; van Oosterhout $\&$ van der Velde, 2014). The largest human settlement in the study area is the city of Chetumal, near the mouth of Hondo River, but other important urban areas lie mainly near the Hondo River main channel (Schmitter-Soto et al., 2011). Detergents, oil derivatives, and domestic sewage are discharged into freshwater bodies in the Hondo basin. These pollutants remain suspended or precipitate, affecting most of the biota present, increasing deformities and mortality, and altering growth, reproduction, feeding, and survival of fish (Cooper, 1993).

Many of the sampling sites, especially in the lower part of the basin, are also used for recreational purposes (rustic pools), which can be harmful to aquatic biota (Allan, 2004) because of ditching, building of dams and other water retaining structures (damaging not only to potamodrome species, but potentially fragmenting all fish populations), clearing of riparian vegetation, and the addition of chemical substances (bleach and detergent) for the maintenance of the sites. In the upper basin, streams provide drinking water for farm animals (pigs and poultry). Canalization of the sites alters the evaporation balance, increases the frequency and magnitude of floods, contributes to the alteration of flow dynamics, and increases erosion and transport of nutrients, sediments and pollutants (Walsh et al., 2005). Altered drainage systems, soil compaction, and modification of the mosaic of natural habitats, patches, and ecotones further affect the diversity of aquatic organisms (Allan et al., 1997). The effects of human settlements are similar to those caused by agriculture (van Sickle et al., 2004).

In the case of pasture for cattle farming, this study found positive values with respect to biotic integrity, a counter-intuitive result that refutes our initial hypothesis with respect to this particular land use. However, the same association was found by Fitzpatrick et al. (2001) in Wisconsin and by Pinto et al. (2006) in Brazil. Both studies reported that an increase in pasture results in a decline of urban uses. Other studies indicated that pasture has a slightly positive effect on ecosystem health (Strayer et al., 2003).

In our study area, pasture can act like natural vegetation: as grass covers the ground most of the year, soil erosion and runoff are avoided. Pasture reduces the concentration of nitrogen and other nutrients in the soil (Laurance et al., 
1999), thus reducing wash-out. Other studies in pasture have shown an increase in microorganism communities that keep nutrient levels stable (Bardgett, Mawdsley, Edwards, \& Hobbs, 1999). Moreover, pasture does not need much input of fertilizers and herbicides relative to other crops in the region (e.g. sugar cane), and burning usually occurs only every two years. These are the likely causes why pasture did not adversely affect aquatic integrity in the Hondo River basin.

Secondary vegetation, in spite of being a more "natural" land use, presented an inverse (although not significant) correlation to the aquatic biotic integrity. This can be explained by the fact that secondary vegetation results from the removal of native vegetation, partly by natural disasters like hurricanes, fires, and floods, but more importantly by human activities, such as land clearing for agriculture and the expansion of urban centers, among others (Gómez-Pompa, 1971). In the upper basin, secondary vegetation is the result of clearing for human settlements and pasture; in the lower basin, it can be attributed to agriculture, human settlements and pasture.

Forests showed a positive correlation with aquatic biotic integrity, as reported by several authors (Omernik, Abernathy, \& Male, 1981; Roth et al., 1996; Fitzpatrick et al., 2001). Forests favor aquatic ecosystems health because they act as traps for nutrients and toxins, retaining and limiting their leakage into water bodies. Forested areas also preserve channel morphology, stabilize flow, and provide organic matter, food and shelter for aquatic organisms. Wetlands showed a positive correlation with respect to biotic integrity, as reported by other authors (Roth et al., 1996; Fitzpatrick et al., 2001). Vegetation in wetlands is important for freshwater ecosystems because it reduces excessive light and temperature, growth of algae and aquatic plants, loss of stability of the sediment, nutrient retention, changes in the quantity and quality of organic matter, and alteration of the trophic structure of the system (Findlay, Quinn, Hickey, Burrell, \& Downes, 2001).
Lower values of the Hondo River IBI are mainly correlated with the scarcity or absence of sensitive species (e.g. Hyphessobrycon compressus [Meek, 1904]), frequent excess of tolerant species (e.g. Rhamdia guatemalensis [Günther, 1864], Astyanax bacalarensis Schmitter-Soto, 2017, Thorichthys meeki Brind, 1918), occasional presence of exotics (Oreochromis mossambicus [Peters, 1852], $O$. niloticus [L., 1758], Pterygoplichthys pardalis [Castelnau, 1855]), dominance of herbivores (e.g. Vieja melanura [Günther, 1862], perhaps due to the proliferation of filamentous algae at organic-enriched sites), or dominance of opportunistic species (e.g. Poecilia mexicana Steindachner, 1863) (Schmitter-Soto et al., 2011). Jones III, Helfman, Harper, and Bolstad (1999) found lower fish abundance as riparian vegetation decreased, mainly because of the loss of benthic species, which were replaced by detritivorous species, tolerant to adverse environmental conditions and even invasive species. Likewise, associated vegetation has proven to be effective in the reduction of nitrogen and phosphorus, in both ground and surface water (Gergel, Turner, Miller, Melack, \& Stanley, 2002). In Costa Rica, Lorion and Kennedy (2009) concluded that riparian vegetation was critical to biotic integrity in tropical streams.

The presence of lentic water bodies showed an inverse correlation with biotic integrity in streams. This is probably because most pollutants are carried and deposited in these aquatic systems, with an enrichment in nutrients from external sources (Carpenter et al., 1998). This condition reflects the presence of livestock, agriculture, and human settlements near water bodies, as many of these systems are devoid of riparian vegetation. The lack of riparian vegetation accelerates the rate and magnitude of pollution from organic matter and pesticides carried by runoff, causing changes in the availability of nutrients because of the loss of processes of filtration provided by forests and riparian vegetation.

Lentic systems function differently from lotic ones, because the mechanical process of degradation of pollutants is low or absent, 
affecting the dilution of harmful substances; in addition, aeration is deficient, so most of the pollutants have a longer life (SchmitterSoto et al., 2002). However, Pinto et al. (2006) found that the presence of lakes and ponds was positive $(r=0.71)$ for biotic integrity in Brazilian streams.

It should be acknowledged that most of the correlations found between land use/cover classes and IBI values were not significant, mostly because of the small sample size. It is desirable to increase the number of sampled localities, so that there is a representation of the differences and relationships between index values and landscape components (Pinto et al., 2006). Nevertheless, our correlations are useful as early warnings (a conclusion similar to Snyder's et al., 2003).

The most detrimental land use/cover was urban use, while the most positive ones were wetlands and forests. The lower basin, where agriculture and human settlements predominate, and where IBI indicates that aquatic environmental health is compromised, should receive attention more urgently. Cattle pastures uses were expected to be detrimental, but were actually positive; secondary vegetation was expected to be positive, but this was not the case. The relationship between landscape and local aquatic integrity is not always intuitively predictable. This conclusion has important implications for management, so we recommend that due attention has to be paid to the interaction between these two levels of complexity for monitoring and restoration programs.

\section{ACKNOWLEDGMENTS}

Thanks to Susannah McCandless for reviewing our English, to the editors and anonymous reviewers for useful comments on the manuscript, to Roberto Herrera for field support, and to Janneth Padilla for help with the figures. The Mexican government issued collecting permit No. DGOPA.04715.240810.2914. This work was financed by project SEMARNAT-CONACYT 2006/01 (23674), and was part of the M.Sc. thesis of the first author.

\section{RESUMEN}

Uso del suelo e integridad biótica en arroyos someros de la cuenca del río Hondo, península de Yucatán, México. Los ambientes acuáticos en la cuenca del río Hondo, sureste de la península de Yucatán, enfrentan diversas amenazas. Algunos de estos impactos, e.g. contaminación por plaguicidas, pueden depender del uso de suelo o cobertura. El objetivo fue evaluar el efecto del uso del suelo/cobertura sobre un índice biótico de integridad (IBI) basado en peces, publicado previamente, diseñado para arroyos someros en esta cuenca. La hipótesis era que los usos del suelo que involucran deforestación y contaminación, entre ellos urbanización, ganadería o cultivo de caña de azúcar, se verían reflejados en valores bajos del IBI, por lo menos a ciertas escalas espaciales. Los 23 sitios usados originalmente para estimar por electropesca la abundancia relativa y otras características de especies y gremios selectos de peces, para construir el IBI, fueron visitados de nuevo en febrero 2010 para validar por inspección directa el tipo de uso del suelo/cobertura sugerido por la información de paisaje en bases de datos digitales. Se analizó el efecto de siete tipos de uso del suelo/cobertura (agricultura, ganadería, asentamientos humanos, cuerpos de agua, humedales, bosque y vegetación secundaria) sobre los valores del IBI, a cuatro escalas espaciales, i.e., el porcentaje de cada uso del suelo/cobertura en círculos progresivamente mayores $(125,250,500$ y $1000 \mathrm{~m}$ de diámetro) centrados en el cuerpo de agua donde se midió el valor del IBI. Los porcentajes de uso del suelo/cobertura por escala se correlacionaron entre sí y con los valores correspondientes del IBI para explorar su asociación; luego, mediante pruebas $t$ de Student se buscaron diferencias significativas en cobertura entre grupos de localidades por encima y por debajo del valor mediano del IBI, así como pruebas $U$ de Mann-Whitney para comparar valores del IBI entre localidades con o sin una cobertura dada. La agricultura, asentamientos humanos y vegetación secundaria mostraron una relación negativa con el IBI, lo cual sugiere un impacto de las actividades humanas sobre la salud de los ecosistemas acuáticos. Las diferencias fueron significativas para el bosque (mayor en sitios con mejor integridad acuática) y los asentamientos humanos (menor en sitios con mayor valor del IBI). De todas las clases paisajísticas en la cuenca del río Hondo, las de origen antrópico, excepto los pastizales para ganadería, tendieron a ser perjudiciales para la integridad biótica acuática.

Palabras clave: impacto humano, peces, riesgo ambiental, variación del paisaje, índice biótico de integridad, diversidad acuática. 


\section{REFERENCES}

Allan, J. D. (2004). Landscapes and riverscapes: the influence of land use on stream ecosystems. Annual Review of Ecology, Evolution, and Systematics, 35(2002), 257-284. http://doi.org/10.1146/annurev. ecolsys.35.120202.110122

Allan, J. D., Erickson, D. L., \& Fay, J. (1997). The influence of catchment land use on stream integrity across multiple spatial scales. Freshwater Biology, 37(1), 149-161. http://doi.org/10.1046/j.1365-2427.1997. d01-546.x

Arriaga Cabrera, L., Espinosa-Rodríguez, J. M., AguilarZúñiga, C., Martínez-Romero, E., Gómez- Mendoza, L., \& Loa, E. (2000). Regiones terrestres prioritarias de México. Mexico City: Comisión Nacional para el Conocimiento y Uso de la Biodiversidad.

Bardgett, R. D., Mawdsley, J. L., Edwards, S., \& Hobbs, P. J. (1999). Plant species and nitrogen effects on soil biological properties of temperate upland grasslands. Ecology, 13, 650-660.

Buenfil-Rojas, A. M., Álvarez-Legorreta, T., \& CedeñoVázquez, J. R. (2014). Metals and metallothioneins in Morelet's crocodile (Crocodylus moreletii) from a transboundary river between Mexico and Belize. Archives of Environmental Contamination and Toxicology, 68(2), 265-273. http://doi.org/10.1007/ s00244-014-0088-5

Carpenter, S. R., Caraco, N. F., Correll, D. L., Howarth, R. W., Sharpley, A. N., \& Smith, V. H. (1998). Nonpoint pollution of surface waters with phosphorus and nitrogen.Ecological Applications, 8(1998), 559-568. http:// doi.org/10.1890/1051-0761(1998)008[0559:NPOSW $\mathrm{W}] 2.0 . \mathrm{CO} ; 2$

Castellanos, M. B. (2010). A return to servitude: Maya migration and the tourist trade in Cancun. Minneapolis: University of Minnesota Press.

Cooper, C. M. (1993). Biological effects of agriculturally derived surface water pollutants on aquatic systems-a review. Journal of Environmental Quality, 22(3), 402-408.

Córdova-Ávalos, A., Alcántara-Carbajal, J. L., GuzmánPlazola, R., Mendoza-Martínez, G. D., \& GonzálezRomero, V. (2009). Desarrollo de un Índice de Integridad Biológica Avifaunístico para dos asociaciones vegetales de la Reserva de la Biósfera Pantanos de Centla, Tabasco. Universidad y Ciencia, 25(1), 1-22. Retrieved from http://www.publicaciones.ujat. $\mathrm{mx} /$ publicaciones/uciencia/abril2009/1--340.pdf

Di Rienzo, J. A., Casanoves, F., Balzarini, M. G., Gonzalez, L., Tablada, M., \& Robledo, C. W. (2008). InfoStat, versión 2008. Grupo InfoStat. Córdoba, Argentina: FCA, Universidad Nacional de Córdoba.
Environmental System Research Institute (ESRI). (1999). ArcView GIS. Version 3.2. New York: Environmental Systems Research Institute.

Esselman, P. C., Schmitter-Soto, J. J., \& Allan, J. D. (2013). Spatiotemporal dynamics of the spread of African tilapias (Pisces: Oreochromis spp.) into rivers of northeastern Mesoamerica. Biological Invasions, 15(7), 1471-1491. http://doi.org/10.1007/ s10530-012-0384-9

Findlay, S., Quinn, J. M., Hickey, C. W., Burrell, G., \& Downes, M. (2001). Effects of land use and riparian flowpath on delivery of dissolved organic carbon to streams. Limnology and Oceanography, 46(2), 345355. http://doi.org/10.4319/1o.2001.46.2.0345

Fisch, F., Branco, J. O., \& Menezes, J. T. de. (2016). Ictiofauna como indicador de la integridad biótica de un ambiente estuarino. Acta Biológica Colombiana, 2121(11), 27-3827. http://doi.org/10.15446/abc. v2 $\ln 1.46151$

Fitzpatrick, F. A., Scudder, B. C., Lenz, B. N., \& Sullivan, D. J. (2001). Effects of multiscale environmental characteristics on agricultural stream biota in eastern Wisconsin. Journal of the American Water Resources Association, 37(6), 1489-1507. http://doi. org/10.1017/CBO9781107415324.004

Fore, L. S. (2002). Response of diatom assemblages to human disturbance: development and testing of a multimetric index for the Mid-Atlantic Region (USA). In T. P. Simon (Ed.), Biological response signatures: indicator patterns using aquatic communities (pp. 445-480). Boca Raton, FL: CRC.

García, G., \& Secaira, F. (2006). Una visión para el futuro: cartografia de las selvas maya, zoque $y$ olmeca: plan ecorregional de las selvas maya, zoque y olmeca. San José, Costa Rica: TNC Infoterra, Conservation International.

Gergel, S. E., Turner, M. G., Miller, J. R., Melack, J. M., \& Stanley, E. H. (2002). Landscape indicators of human impacts to riverine systems. Aquatic Sciences, 64, 118-128.

Gómez-Pompa, A. (1971). Posible papel de la vegetación secundaria en la evolución de la flora tropical. Biotrópica, 3(2), 125-135.

Instituto Nacional de Estadística Geografía e Informática (INEGI). (2009). Mapa digital de México. Retrieved January 1, 2010, from http://gaia.inegi.org.mx/ mdm5/viewer.html

Intergovernmental Panel on Climate Change (IPCC). (2013). The Physical Science Basis. Contribution of Working Group I to the Fifth Assessment Report of the Intergovernmental Panel on Climate Change. New York. 
Jones III, E. B. D., Helfman, G. S., Harper, J. O., \& Bolstad, P. V. (1999). Effects of riparian forest removal on fish assemblages in southern Appalachian streams. Conservation Biology, 13(6), 1454-1465.

Karr, J. R. (1981). Assessment of biotic integrity using fish communities. Fisheries, 6(6), 21-27. http://doi. org/10.1577/1548-8446(1981)006<0021:AOBIUF>2 $0 . \mathrm{CO} ; 2$

Laurance, W. F., Fearnside, P. M., Laurance, S. G., Delamonica, P., Lovejoy, T. E., Rankin-De Merona, J. M., ..., Gascon, C. (1999). Relationship between soils and Amazon forest biomass: a landscape-scale study. Forest Ecology and Management, 118(1-3), 127-138. http://doi.org/10.1016/S0378-1127(98)00494-0

Lorion, C. M., \& Kennedy, B. P. (2009). Riparian forest buffers mitigate the effects of deforestation on fish assemblages in tropical headwater streams. Ecological Applications, 19(2), 468-479.

Lowry, R. (2016). VassarStats: website for statistical computation. Retrieved October 1, 2016, from http:// vassarstats.net/index.html

Miranda, F. (1958). Estudios acerca de la vegetación. In E. Beltrán (Ed.), Los recursos naturales del sureste y su aprovechamiento (Vol. 2, pp. 215271). Mexico City: Instituto Mexicano de Recursos Naturales Renovables.

Naiman, R. J., Bechtold, S., Drake, D. C., Latterell, L. L., O'Keefe, T. C., \& Balian, E. V. (2005). Origins, patterns, and importance of heterogeneity in riparian systems. In G. Lovett, C. G. Jones, M. G. Turner, \& K. C. Weathers (Eds.), Ecosystem Function in Heterogeneous Landscapes (pp. 279309). New York: Springer.

Omernik, J. M., Abernathy, A. R., \& Male, L. M. (1981). Stream nutrient levels and proximity of agricultural and forest land to streams: some relationships. Journal of Soil and Water Conservation, 36(4), 227-231.

Pacheco Díaz, R. I. (2011). Efectos del paisaje sobre un indice biótico de integridad en el río Hondo (M.Sc. Thesis). El Colegio de la Frontera Sur, Chetumal, Mexico.

Pinto, B. T., Araújo, F. G. C., \& Hughes, R. M. (2006). Effects of landscape and riparian condition on a fish index of biotic integrity in a large southeastern Brazil river. Hydrobiologia, 556(1), 69-83. http://doi. org/10.1007/s10750-005-9009-y

Richards, C., \& Host, G. E. (1994). Examining land influences on stream habitat and microinvertebrates: A GIS approach. Journal of the American Water Resources Association, 30(4), 729-738.

Roth, N. E., Allan, J. D., \& Erickson, D. L. (1996). Landscape influences on stream biotic integrity assessed at multiple spatial scales. Landscape Ecology, 11(3), 141-156. http://doi.org/10.1007/BF02447513

Sánchez, A. J., Álvarez-Legorreta, T., Pacheco, J. G., Carri1lo, L., \& González, R. A. (2016). Calidad del agua subterránea: acuífero sur de Quintana Roo, México. Tecnología y Ciencias del Agua, 7(4), 75-96.

Schmitter-Soto, J. J. (2014). Los índices bióticos de integridad en el monitoreo ambiental. In C. González-Zwarth, A. Vallarino, J. C. Pérez, \& A. Low Pfeng (Eds.), Bioindicadores: guardianes de nuestro futuro ambiental (pp. 61-78). Mexico City: INECC, ECOSUR.

Schmitter-Soto, J. J., \& Caro, C. I. (1997). Distribution of tilapia, Oreochromis mossambicus (Perciformes: Cichlidae), and water body characteristics in Quintana Roo, Mexico. Revista de Biología Tropical, 45(3), 1257-1261.

Schmitter-Soto, J. J., Comín, F. A., Escobar-Briones, E., Herrera-Silveira, J., Alcocer, J., Suárez-Morales, E., ..., Steinich, B. (2002). Hydrogeochemical and biological characteristics of cenotes in the Yucatán Peninsula (SE Mexico). Hydrobiologia, 467, 215228. http://doi.org/10.1023/A:1014923217206

Schmitter-Soto, J. J., Quintana, R., Valdéz-Moreno, M. E., Herrera-Pavón, R. L., \& Esselman, P. C. (2015). Armoured catfish (Pterygoplichthys pardalis) in the Hondo River basin, Mexico-Belize. Mesoamericana, 19(3), 9-19.

Schmitter-Soto, J. J., Ruiz-Cauich, L. E., Herrera-Pavón, R. L., \& González-Solís, D. (2011). An Index of Biotic Integrity for shallow streams of the Hondo River basin, Yucatán Peninsula. Science of the Total Environment, 409(4), 844-852. http://doi.org/10.1016/j. scitotenv.2010.11.017

Snyder, C. D., Young, J. A., Villella, R., \& Lemarié, D. P. (2003). Influences of upland and riparian land use patterns on stream biotic integrity. Landscape Ecology, 18, 647-664. http://doi.org/10.1023/ B:LAND.0000004178.41511.da

Strayer, D. L., Beighley, R. E., Thompson, L. C., Brooks, S., Nilsson, C., Pinay, G., \& Naiman, R. J. (2003). Effects of land cover on stream ecosystems: Roles of empirical models and scaling issues. Ecosystems, 6(5), 407-423. http://doi.org/10.1007/s10021-002-0170-0

van Oosterhout, M. P., \& van der Velde, G. (2014). An advanced Index of Biotic Integrity for use in tropical shallow lowland streams in Costa Rica: Fish assemblages as indicators of stream ecosystem health. Ecological Indicators, 48, 687-698. http://doi. org/10.1016/j.ecolind.2014.09.029

van Sickle, J., Baker, A., Herlihy, P., Bayley, S., Gregory, P., Ashkenas, L., \& Li, J. (2004). Projecting the biological condition of streams under alternative 
scenarios of human land use. Ecological Applications, 14(2), 368-380.

Walsh, C. J., Roy, A. H., Feminella, J. W., Cottingham, P. D., Groffman, P. M., \& Morgan II, R. P. (2005) The urban stream syndrome: current knowledge and the search for a cure. Journal of the North American Benthological Society, 24(3), 706-723. http://doi. org/10.1899/04-028.1

Wang, L., Lyons, J. D., Kanehi, P., Bannerman, R., \& Emmons, E. (2000). Watershed urbanization and changes in fish communities in southeastern Wisconsin streams. Journal of the American Water Resources Association, 36(5), 1173-1189. http://doi. org/10.1111/j.1752-1688.2000.tb05719.x

Wichert, G. A., \& Rapport, D. J. (1998). Fish community structure as a measure of degradation and rehabilitation of riparian systems in an agricultural drainage basin. Environmental Management, 22(3), 425-443. http://doi.org/10.1007/s002679900117

Wilcox, D. A., Meeker, J. E., Hudson, P. L., Armitage, B. J., Black, M. G., \& Uzarski, D. G. (2002). Hydrologic variability and the application of Index of Biotic Integrity metrics to wetlands: A great lakes evaluation. Wetlands, 22(3), 588-615. http:// doi.org/10.1672/0277-5212(2002)022[0588:HVATA $\mathrm{O}] 2.0 . \mathrm{CO} ; 2$

Yu, K., DeLaune, R. D., Tao, R., \& Beine, R. L. (2008). Nonpoint source of nutrients and herbicides associated with sugarcane production and its impact on Louisiana coastal water quality. Journal of Environmental Quality, 37(6), 2275-2283. 